\title{
Collaborative Governance for Poverty Alleviation: A Systematic Mapping Study
}

\author{
M.A. Muslim, E. Prasojo, L.M. Jannah \\ University of Indonesia, \\ Jl. Salemba Raya No. 4, RW. 5, Jakarta, Indonesia, 10430
}

\begin{abstract}
The study of poverty reduction is very relevant in the 21 st century. The rapid development of technology has proven to improve various quality of life but has not been able to solve the problem of poverty in a total scale. On the other hand, the development of public administration science, especially regarding collaborative governance, provides hope for poverty reduction through the active role of various parties. Many experts explain that poverty is a complex problem. Poverty reduction efforts must be carried out in a holistic and participatory manner. Furthermore, there needs to be an active contribution from various parties, namely the government, the private sector and the community. This requires researchers to conduct further studies on how Collaborative Governance can be an alternative solution to solving the problem of poverty. This study aims to delineate the development of Collaborative Governance studies through the Systematic Mapping Study and associate it to the poverty alleviation to obtain the current research position. The study shows that research on Collaborative Governance for Poverty Reduction is included in Social Issues in Community concentration and it has the lowest percentage. The most widely used method in the research concentrated on Collaborative Governance is qualitative, and the publication trend shows a very significant development, especially in 2014-2018. Therefore, research on collaborative governance for poverty alleviation is still very limited and the opportunity to produce variety of renewals is very large.
\end{abstract}

Keywords: collaborative governance, poverty alleviation, systematic mapping study

Conflicts of interest: The authors declared no conflicts of interest.

\section{Article history:}

The article was submitted on 19.10.2020. The article was accepted on 15.11.2020.

\section{For citation:}

Muslim M.A., Prasojo E., Jannah L.M. Collaborative Governance for Poverty Alleviation: A Systematic Mapping Study. RUDN Journal of Public Administration. 2021; 8(1): 20-36. DOI: $10.22363 / 2312-8313-2021-8-1-20-36$

(C) Muslim M., Prasojo E., Jannah L., 2021

(c) (-) This work is licensed under a Creative Commons Attribution 4.0 International License https://creativecommons.org/licenses/by/4.0/ 


\title{
Совместное управление для борьбы с бедностью: системное картирование
}

\author{
М.А. Муслим, Э. Прасойо, Л.М. Джанна \\ Университет Индонезии, \\ 10430, Индонезия, Джакарта, Салемба Райя № 4, Jl, RW.5
}

\begin{abstract}
Аннотация. Изучение сокращения бедности очень актуально в XXI веке. Доказано, что быстрое развитие технологий улучшает различные аспекты качества жизни, но не может в полном объеме решить проблему бедности. С другой стороны, развитие науки о государственном управлении, особенно в том, что касается совместного управления, дает надежду на сокращение бедности благодаря активной роли различных действующих сторон. Многие исследователи и эксперты указывают на комплексный характер проблемы бедности. Усилия по сокращению бедности должны осуществляться комплексно и на основе широкого участия. Более того, необходимо активное участие различных сторон, а именно правительства, частного сектора и общества. Это требует от исследователей проведения дальнейших исследований того, как совместное управление может выступать в качестве альтернативного решения проблемы бедности. Представленное исследование очерчивает развитие исследований по совместному управлению с помощью метода системного картирования и связывает его с сокращением бедности для определения текущей исследовательской позиции. Проведенное исследование показывает, что изучение совместного управления для сокращения бедности не вызывает большого интереса у современных ученых. При анализе совместного управления наиболее широко используются качественные методы, на развитие которых указывает тенденция публикаций в рамках данной темы в изданиях, индексируемых в международных базах данных, особенно в 2014-2018 годах. Таким образом, авторы приходят к выводу о том, что исследований в области совместного управления в целях сокращения масштабов нищеты все еще недостаточно, а возможность разработки инновационных подходов и технологий в этом направлении, напротив, очень велика.
\end{abstract}

Ключевые слова: совместное управление, борьба с бедностью, системное картирование

Заявление о конфликте интересов:

Авторы заявляют об отсутствии конфликта интересов.

История статьи:

Статья поступила в редакцию: 19.10.2020. Статья принята к публикации: 15.11 .2020

\section{Для цитирования:}

Муслим М.А., Прасойо Э., Джанна Л.М. Совместное управление для борьбы с бедностью: системное картирование // Вестник Российского университета дружбы народов. Серия: Государственное и муниципальное управление. 2021. Т. 8. № 1. С. 20-36. DOI: 10.22363/ 2312-8313-2021-8-1-20-36

\section{Introduction}

The global problem encountered by all countries in the world is poverty, and there have been many attempts made by each country to resolve it. However, still almost half of the world's population lives in poverty $[1 ; 2]$. The poverty issue is complex and multidimensional $[2 ; 3 ; 4]$. To handle it requires a multidimensional, integrated, and sustainable approach. Poverty by the World Bank [5] is defined as a deprivation in welfare, while Amartya Sen [6] explains that poverty can occur due to capability deprivation; the freedom to achieve something in one's life. 
Close attention to the poverty issue is shown through a historical declaration called the Millennium Development Goals (MDGs) by the United Nations (UN). This declaration was the result of a meeting by the United Nations (UN) in New York in September 2000, called the Millennium Summit. Subsequent to the end of MDGs implementation in 2015, an advanced international agenda called the Sustainable Development Goals (SDGs) emerged. Inherently, all of the goals of the SDGs are the continuation of the MDGs, this can be seen from the relationship between the two, for instance the issue of poverty alleviation that still occupies the first priority [7].

Various programs initiated by the United Nations, both inscribed in the MDGs and SDGs, have more or less shown results. The World Bank as one of the special institutions under the United Nations made a report stating that the world poverty rate decreased by $10 \%$ from 804.2 million in 2016 , to 735.9 million in 2018 [8]. Corresponding with the report, World Bank President Jim Yong Kim at the IMF Annual Plenary Meeting - World Bank Group 2018 in Bali acknowledged that the progress of poverty reduction at the global level was still relatively slow, hence according to him, it needed to be pushed so that the poverty rate could be further reduced through the three points that become the strategic keys. These three points are encouraging inclusive and sustainable economic growth through private sector investment, taking immediate actions to climate change, and investing more in human resources.

In the practice of handling various poverty issues, it will be influenced by the dynamics that occur in governance more or less. The large numbers of policies and programs prepared, and the involvement of many institutions are meaningless when they are not equipped with good governance [9]. Cooperation involving many parties that aims the same goals can be understood as a collaboration, as explained by Mattessich et al [10] that a collaboration is an attempt to unite several organizations, that has not previously known each other, merged into a new structure with a commitment to cooperate in an attempt to achieve similar goals.

Collaborative Governance has been implemented to deal with various complex issues such as handling the environment, security, corruption and various other problems, as revealed by Donahue [11] that when the government has a task that depends on the capacity of external parties, one of the methods used is by doing collaboration, involving actors according to the required capacity. The distinguishing factors are on the focus of the problem, the structure, the process, the objectives and the impact [12]. The differences remained in conducting studies on collaborative governance practices have become the attraction for conducting further studies on different issues.

However, there are still very few studies on collaborative governance that deal with poverty. Thus, we need a systematic study to find out the development of the concept of Collaborative Governance, especially in relation to the topic of poverty. Even though the two concepts are related to each other [4]. Collaborative Governance is believed by the experts as the solution to chronic social issues that were previously difficult to solve through various pragmatic attempts. Therefore, this study uses the concept of Collaborative Governance and the concept of Poverty to see the dynamics of the development of Collaborative Governance 
studies and its relation to the concept of poverty that is interesting to be studied, and to study further about its implementation as a new trend and phenomenon.

In this mapping study, five sources are used as references. The five sources are Scopus, Oxford Academic, ProQuest, Sage, JSTOR. These sources were chosen as the ground theory to look at the problem of Collaborative Governance in answering the issue of poverty holistically. Furthermore, this article is solely used to answer these following three research questions:

1. What is the focus of collaborative governance research?

2. What are the method and the research type of the mapping that have been completed?

3. What is the publication trend on collaborative governance research from 2013 to 2019 ?

The concept used in this study is Collaborative Governance, and the concept of poverty. The two concepts are interrelated. Collaborative Governance is trusted by experts as a solution to chronic social problems that were previously difficult to solve through various pragmatic efforts. One of these problems is poverty.

\section{Collaborative Governance}

The first concept to be explained is Collaborative Governance. The understanding of the concept of Collaborative Governance can be viewed from several aspects. Firstly, from the etymology side. Collaborative Governance consists of two entities, namely the "Collaborative" entity and the "Governance" entity. "Governance" as the main pillar with its complement called "Collaborative". The United Nations Economic and Social Commission for Asia and the Pacific notes "Governance" as a process of making decisions by which the decision is implemented. Emerson, Tina and Stephen [12] noted "Governance" as an activity "to govern" or govern / rule / manage. "Collaborative" in the context of public administration is a condition when every stakeholder cooperates with the government to develop a public policy to solve public problems [13]. The two entities then merged into the concept of "Collaborative Governance" described by Purdy [13] as: "a process that seeks to share power in decision making with stakeholders in order to develop shared recommendations for effective, lasting solutions to public problems".

The concept of Collaborative Governance is seen by Purdy [13] as a collaborative process of power from several stakeholders to develop effective and sustainable solutions. Emerson, Tina and Stephen [12] define Collaborative Governance as: "the processes and structures of public policy decision making and management that engage people contractively across the boundaries of public agencies, levels of government, and/or the public, private and civic spheres in order to carry out a public purpose that could not otherwise be accomplished".

The points that can be drawn from the definition by Emerson, Tina and Stephen [12] are that Collaborative Governance is a process that occurs across borders (across the boundaries); involving several executors from various sectors and strive to achieve a vision that cannot be achieved without collaboration between them. Cross-border means that the activities of achieving mission and the preparation of solutions are not only done in a fragmented manner separated by 
lines of separation of authority. The problems faced by public are not faced by individuals but instead together as a group. These cross-border points are related to the next point, namely the actors involved in Collaborative Governance. Emerson, Tina and Stephen [12] explained that there are three parties involved, namely public sector and government, private sector and civic spheres. Authority, power, and resources are merged in collaboration to achieve solution. This is what is meant by the third point in the definition of Collaborative Governance by Emerson, Tina and Stephen [12] that there is a goal that can only be achieved when there is performance collaboration between actors / authorities / stakeholders. Therefore, etymologically, Collaborative Governance is a decisionmaking process that involves the stakeholders from the public sector, the private sector, the non-private sector, and the community to solve public problems.

McDougall [14] asserted that the parties or the sectors project have three distinct characteristics, which are: 1) consciously and explicitly base decision making in social learning and critical reflection, 2) emphasize inclusion and equity in governance and 3) strive for balanced and strategic relations with other actors or groups, including seeking to effectively manage conflict.

Emerson and Nabatchi [12] explained further about Collaborative Governance through illustrations of interrelated component boxes. The components in the Collaborative Governance framework are three main boxes. The outer box is called the system context, the box in the middle is the Collaborative Governance regime, and the inner box or core box is the dynamics of collaboration. System context is an environment where public problems occur or can be understood as the context in which the collaboration process is carried out. The context of this system includes social conditions that occur at a particular place and time. These conditions include political aspects, applicable regulations or legalities, socioeconomic conditions of the community, geographical conditions, and other environmental factors. The context of this system gives influences in two forms, which are opportunities and constraint. The two forms of influence directly affect two boxes within the Collaborative Governance framework, namely the collaboration regime and the dynamics of collaboration. The two influences metamorphose into the drivers that provide input and determine the direction of the dynamic process of collaboration that occurs. Drivers that appear can be public problems or shared problems, uncertainty, interdependence, and so on.

The second box is the Collaborative Governance regime. Drivers that emerge from the outermost box (context) are then adapted by the existing regime to be further processed in the box of collaboration dynamics. The regime referred to is "sets of implicit and explicit principles, rules, norms, and decision-making procedures around which actors" [12]. The principles, rules, norms and procedures adopted by a particular regime in a particular region at certain times directly influence the process of collaboration dynamics that occurs in the next box in the Collaborative Governance framework.

The third box or core box of the Collaborative Governance framework is a box of collaboration dynamics. There are three components that interact with each other in this dynamic box, namely principled engagement, shared motivation, and 
capacity for joint action. The first component is the principle relationship, which is a basis that becomes the foundation of the binding collaboration between the actors involved. This component consists of several things, namely discovery, definition, deliberation and determination. Discovery is when the actors find a problem. Definition is a defining process of a problem that is found. Deliberation is an in-depth discussion between actors to consider collaborative activities. Determination is the intention / determination between actors to be involved in a collaborative problem solving. The second component is collective motivation which is held firmly with commitment. The things covered in this second component are mutual trust, mutual understanding, internal legitimacy, and shared commitment. Illustration of the form of a Collaborative Governance framework can be seen in Figure 1. below.

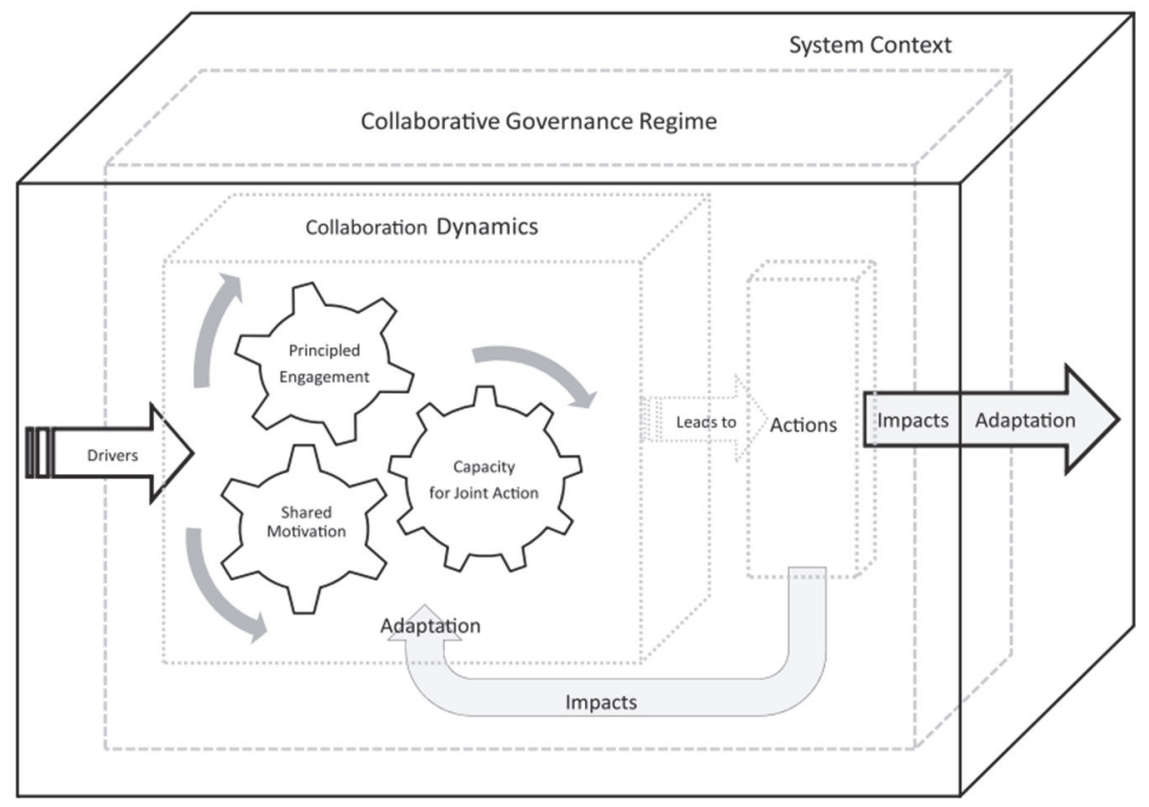

Fig. 1. Collaborative Governance sebagai Kerangka Kerja

Source: Emerson and Nabatchi [12].

Ansell and Gash [15] have previously developed a Collaborative Governance model. The visible characteristics also dwell on a process from input to output. The input component described by Ansell and Gash [15] is called the "Starting Conditions". This initial condition is formed from two main factors, namely the existence of asymmetry of power, resources, and knowledge; and the history of cooperation and also conflicts that have occurred. Ansel and Gash [15] refer to the factors as "Incentives for and Constraints on Participation". This condition is a bargaining power that encourages or inhibits the intention between actors to initiate collaboration. The existing input components become influences or materials which then enter into the process component. The process component is called "Collaborative Process" and it consists of five stages. First, the stage of interface dialogue or direct dialogue between collaborating actors. Second, developing trust between actors. Third, the stage of implementing commitment to the collaborative process consists of three things, namely the awareness of mutual 
dependence between actors, the sense of belonging of the process (shared ownership of process), and mutual openness. Fourth, the stages of achieving mutual understanding. The fourth stage consists of three things, namely the existence of a clear mission, the existence of a clear problem definition, and the existence of mutually agreed values. Fifth, short-term output stages of production. Long-term products from "Collaborative Process" are long-term output or outcomes. "Collaboration Process" is influenced by the institutional design of the actors involved. The point that distinguishes the opinion of Ansell and Gash [15] with Emerson [12] is the "Facilitative Leadership" component that influences, empowers, and develops the process stage of the "Collaboration Process". The description of the Collaborative Governance model by Ansell and Gash [15] is illustrated in Figure 2.

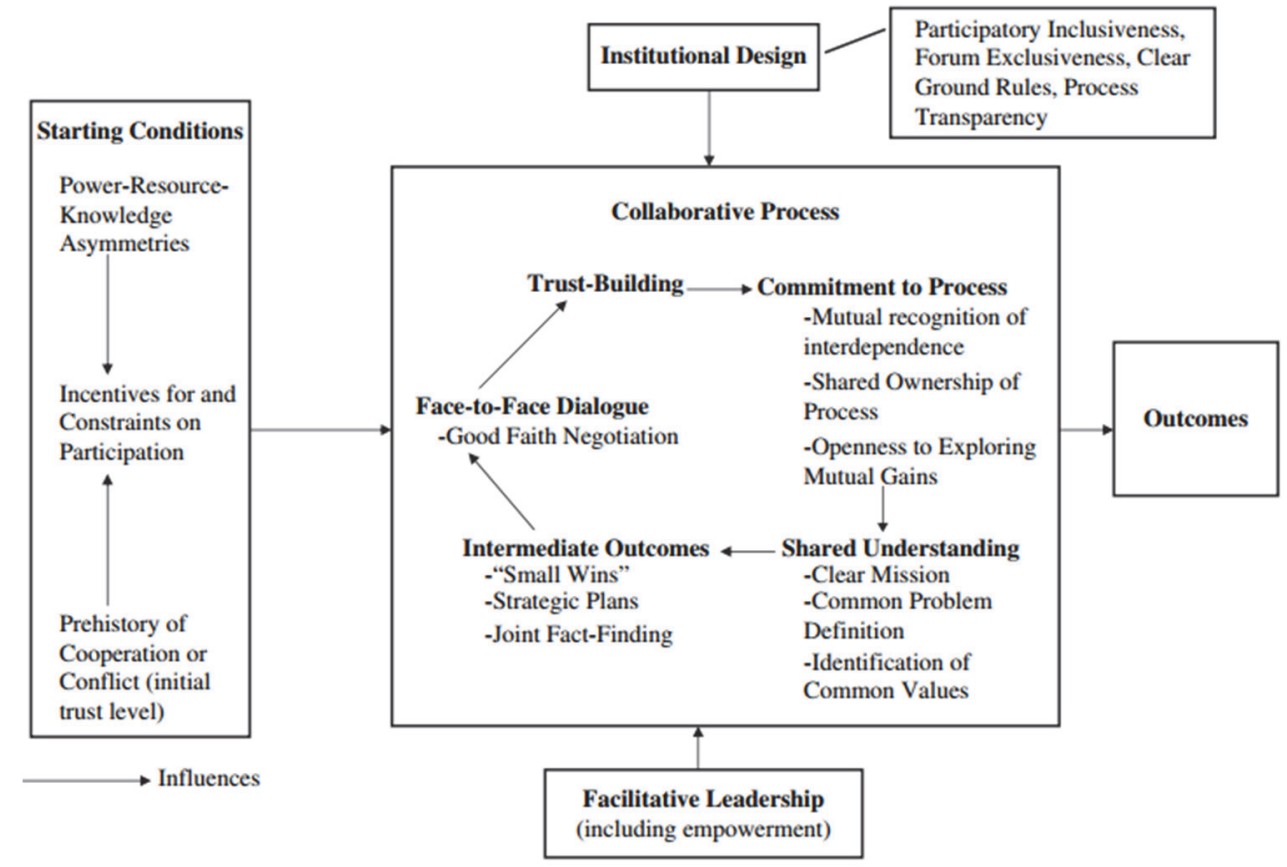

Fig. 2. Model of Collaborative Governance According to Ansell and Gash Source: Ansell and Gash [15].

\section{Poverty}

The next concept in this research is the concept of poverty. The definition of poverty has different meanings depending on the culture and level of economic development of a region [16]. The definition of poverty is a minimum standard of quality of life. The context of minimum here is the lack of meeting an individual's needs compared to the standard of needs that are common in the area or in the community where the person is living. The impact of the lack of quality of life for individuals who experience it is health disorder, morals, and feelings towards the level of self-esteem that is branded as poor [17]. Furthermore, Suparlan [17] defines poverty as a state of shortage of valuable assets and objects suffered by a person or group of people living in a poor environment, so that various fulfillment of needs as human beings becomes completely limited or inadequate. In line with 
the previous view, Gilarso [18] states that poverty is a condition where the population cannot fulfill basic needs because there is no income to obtain them. Chamsyah [19] explains: "Poverty is a concern with absolute standards of living of the poor in the equality of standards across the whole society". To put it simply, the World Bank in the year 2000 sees poverty as a deficiency, which is often measured by the level of welfare.

Marianti and Munawar [20] argue that poverty is a multidimensional phenomenon, defined, and measured in many ways. In many cases, poverty has been measured by welfare terminology related to the economy, such as income and consumption. A person is said to be poor if he what makes is below the minimum level of welfare that has been agreed upon. It is true that poverty is a problem arises from low income, but it is not the only source of poverty, which is a complex problem. By incorporating more comprehensive considerations such as health and education, the United Nations defines poverty as a condition where individuals have no choice and opportunity to develop their life capabilities. In other words, poverty is a pronounced deprivation in well-being condition or a continuous decline in quality of life [21].

Tostensen and Kessy [22] explain that poverty has three dimensions, which are deprivation where the condition of poverty can indicate that someone is deprived of basic needs such as food, shelter, education, or health. Second, vulnerability where the poor are vulnerable to the ever-changing situations, such as economic fluctuations, natural disasters, or war. Third, powerlessness is a condition characterized by a lack of skills, so that the person is struggling be get out of the poverty line.

Normatively, poverty can be divided into two categories [19]. First is absolute poverty that is if the level of income is lower than the defined poverty line, or in other words the amount of income is insufficient to meet the minimum living needs reflected in the absolute poverty line. The lowest income level or commonly known as the minimum wage is the dividing point between two conditions, namely poor conditions and non-poor conditions. This point is also known as the poverty line [23]. Second, relative poverty is a state of comparison between income groups in society, namely groups that may not be poor because they have higher income than the poverty line, and relatively richer community groups. The point is when an individual is above the poverty line but when compared to the general ability of the community where the individual lives is still lower, it can be said that the individual can still be categorized as poor [23]. Another view explains poverty can be divided into three categories [24]. First, natural poverty is poverty caused by natural causes. For example, geographical conditions that do not support basic fulfillment or slow technological development. Second, structural poverty, namely poverty caused by the inability of a group or community to form an institution capable of mastering production factors or economic facilities. Third is cultural poverty, namely poverty related to tradition or the mentality of a lazy population. Another category of poverty is the level of vulnerability of poverty, where poverty is divided into chronic poverty or structural poverty and temporary poverty [25]. Structural poverty or also called chronic poverty generally takes place in a sustainable manner. Temporary poverty usually takes place in a shorter period of time and is caused by sudden economic 
changes or an economic crisis [19]. Third is cultural poverty, namely poverty related to tradition or the mentality of a lazy population. Another category of poverty is the level of vulnerability of poverty, where poverty is divided into chronic poverty or structural poverty and temporary poverty [25]. Structural poverty or also called chronic poverty generally takes place in a sustainable manner. Temporary poverty usually takes place in a shorter period of time and is caused by sudden economic changes or an economic crisis [19].

\section{Research Method}

Understanding the research position (State of the Art) is important in conducting a study. Based on this, researchers can find out whether the research carried out really has novelty or something new in its findings. Thus, in order to find a research position on the topic of Leadership in Collaborative Governance for Poverty Reduction, researchers conducted a Systematic Mapping Study. Researchers use electronic databases to find articles that discuss Collaborative Governance (CG).

The tools of analysis used in this study are the Systematic Mapping Study. According to Kitchenham [26] the Systematic Mapping Study (SMS) is a secondary study rooted in Study Literature Review (SLR), which was initially introduced to medical research. The implementation of SLR is to identify, evaluate, and interpret all available and relevant literature related to research questions or domains of interest [26, 27]. Kitchenham [28] states that the main reasons for conducting SLR are: first, summarize the available evidence on the topic; second, to identify gaps in current research and provide suggestions for future investigations; and third, to provide a background for positioning new research activities.

\section{Research Questions}

The research question in this paper is to concentrate on categorizing research with the topic of Collaborative Governance and the position of poverty research as one of the focuses in Collaborative Governance research. Below is Table 1 that shows the overall research questions:

Table 1

\section{Research Questions and Descriptions}

\begin{tabular}{|c|c|}
\hline Questions & Descriptions \\
\hline $\begin{array}{l}\text { How is the spread of research focus } \\
\text { on the topic of Collaborative } \\
\text { Governance? What is the position of } \\
\text { research on poverty as one of the } \\
\text { focuses of Collaborative } \\
\text { Governance? }\end{array}$ & $\begin{array}{l}\text { The result provides a general description of the } \\
\text { distribution of the focus of Collaborative Governance } \\
\text { research. In addition to that, the results also show how } \\
\text { the position of poverty research is one of the focuses in } \\
\text { Collaborative Governance research. }\end{array}$ \\
\hline $\begin{array}{l}\text { What are the methods and types of } \\
\text { research from mapping that have } \\
\text { been done? }\end{array}$ & $\begin{array}{l}\text { Investigation of methods and types of research. The } \\
\text { results of the investigation can show the research gap } \\
\text { from previous research. }\end{array}$ \\
\hline $\begin{array}{l}\text { What is the trend of the publication of } \\
\text { Collaborative Governance research } \\
\text { from time to time (2013 to 2019)? }\end{array}$ & $\begin{array}{l}\text { This question shows trends from the publication of } \\
\text { Collaborative Governance research from time to time } \\
\text { (2013 to 2019) }\end{array}$ \\
\hline
\end{tabular}

Source: Modified by the researcher according to Banaeianjahroni \& Smolander [29]. 


\section{Steps of Findings}

The SMS study in this research adopted an investigation process from Petersen et al. [27]. In this SMS process, every step that is taken has results and systematic maps. In Figure 3, the researcher illustrates the complete SMS process used in research, referring to research conducted and according to instructions by Kitchenham [28] and Petersen et al [27].

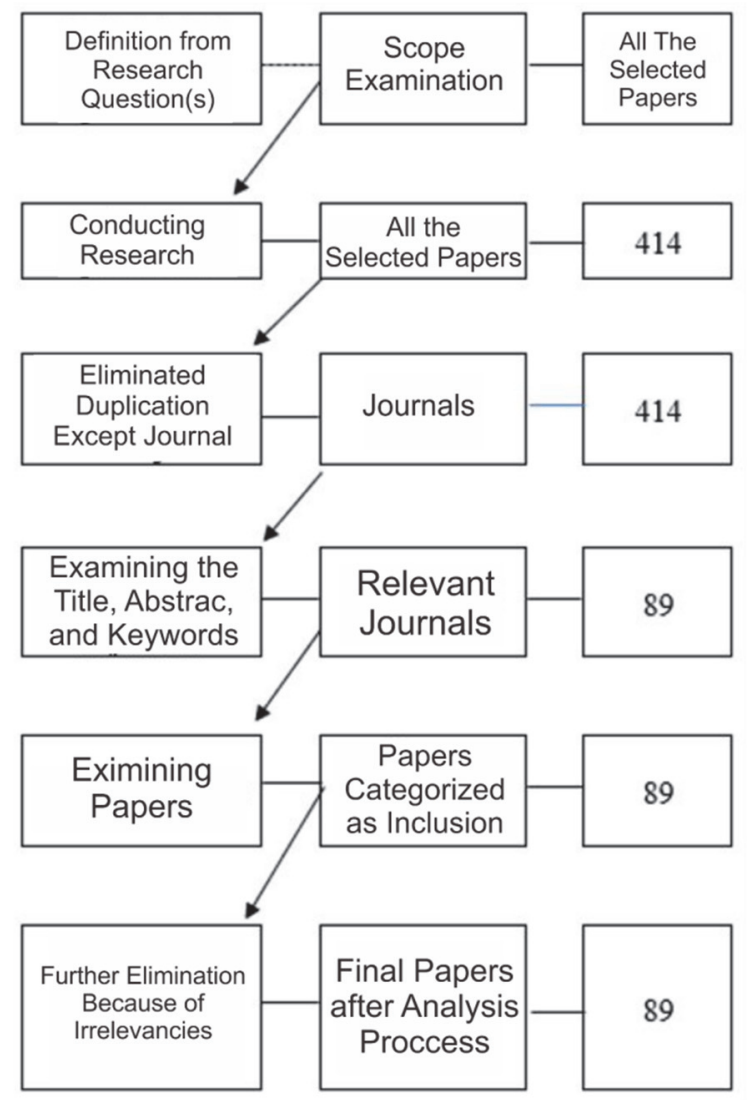

Fig. 3. SMS Inclusion Process

Source: $[28 ; 27]$.

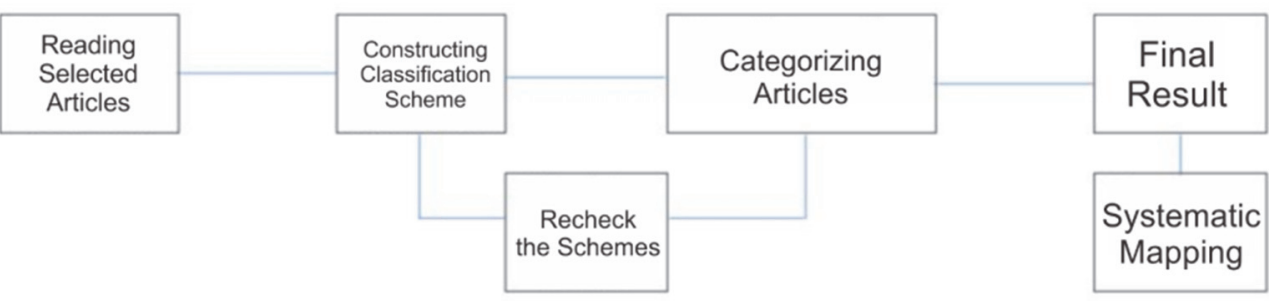

Fig. 4. Classification Process

Source: [27].

\section{Source of Data}

Researchers conduct searches online on electronic databases with the following description: 
The Result of Journals from Electronic Database

\begin{tabular}{llll}
\hline Source Name & $\begin{array}{l}\text { All CG } \\
\text { Journals }\end{array}$ & Journals & Relevant Journals \\
\hline Scopus & 331 & 331 & 37 \\
Oxford Academic & 14 & 14 & 11 \\
ProQuest & 29 & 29 & 18 \\
Sage & 20 & 20 & 12 \\
JSTOR & 20 & 20 & 11 \\
Total & 414 & 414 & 89 \\
\hline
\end{tabular}

In the research of the Systemic Mapping Study, the researcher collected 89 articles, which were then analyzed to find the focus of the research, the scope of the research and the trends of publication from year to year.

\section{Classification Scheme}

In this study, the researcher developed a classification scheme. This scheme later became the basis for conducting analysis and classification of articles from Petersen et al. (2008) as shown in Figure 4. The table provided below (table 3) describes the process of article classification.

Table 3

\section{Classification Categories}

\begin{tabular}{ll}
\hline Research Type & Explanation \\
\hline Validation & $\begin{array}{l}\text { New investigation methods and have not been applied in practice. } \\
\text { (experiment / observation) }\end{array}$ \\
$\begin{array}{l}\text { Research } \\
\text { Evaluation }\end{array}$ & $\begin{array}{l}\text { The investigation method is implemented in practice and is presented in } \\
\text { the evaluation method }\end{array}$ \\
Research & The solution to the problem is proposed, the proposed solution can be a \\
Solution Proposal & new or applicable approach and the existing approach. \\
Philosophical & $\begin{array}{l}\text { This research introduces a new perspective on something that exists using } \\
\text { taxonomy or conceptual framework. }\end{array}$ \\
Paper & This research is based on the author's personal experience of what and \\
Experience Paper & how something has been done in practice. \\
Methods & Explanation \\
Qualitative & Qualitative methods are presented Rapid Assessment Process, journals and \\
Method & language analysis. \\
Quantitative & Quantitative methods are presented with sample designs, hypotheses and \\
Method & tests, all of which are statistical formulations. \\
\hline
\end{tabular}

Source: [30; 27]

\section{Result and Discussion}

Focus Spread on Collaborative Governance. This section describes the focus of research. The researcher classified 89 articles in the research topic area with categories: Water Management, Health, Community Social Problems (Poverty, food security etc.), Regional Planning and Development, Collaborative Governance Actors, Collaborative Governance Dynamics, and Ecological or Natural Resources problems. 


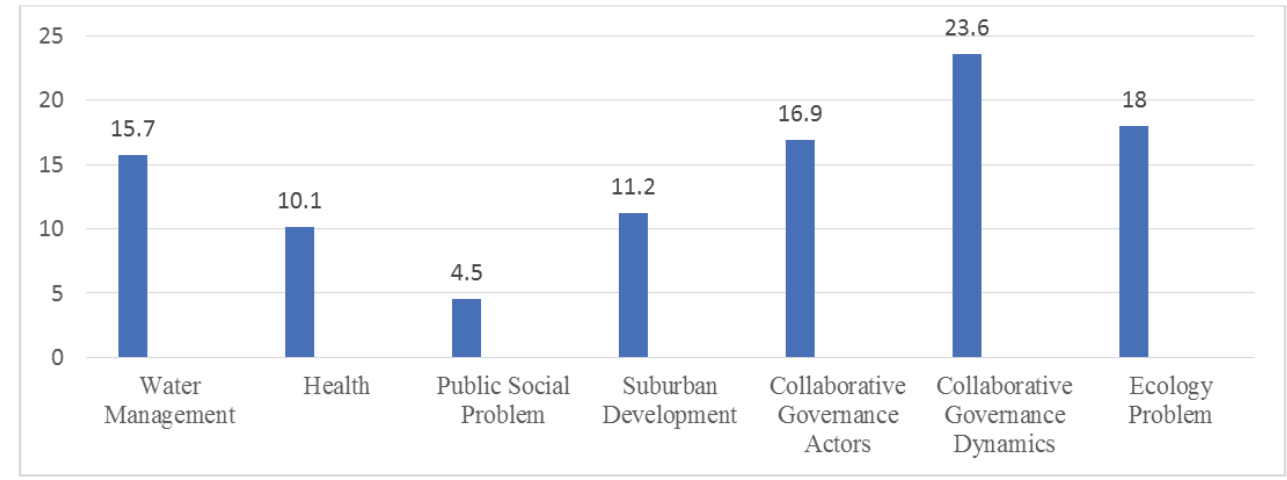

Fig. 5. The Percentage of Research Focuses

Source: The Result of Systematic Mapping Study, 2019.

Figure 5 is an illustration of the distribution rate of research focus on the topic of Collaborative Governance. The most studied research focus is Collaborative Governance Dynamics as many as $21(23.6 \%)$ articles, Ecology or Natural Resources Problems as many as 16 (18\%) articles, Collaborative Governance Actors as many as 15 (16.9\%), Water Management as many as 14 (15.7\%) articles, Regional Planning and Development as many as $10(11.2 \%)$ articles, Health as many as $9(10.1 \%)$ articles, and finally Community Social Problems as many as $4(4.5 \%)$ articles. Further elaboration in the form of a table of research focus can be seen in Table 4 below.

Table 4

The Spread of Research Focus

\begin{tabular}{lll}
\hline Research Focus & Amount & Percentage \\
\hline Water Management & 14 & 15,7 \\
Health & 9 & 10,1 \\
Social Issue of the Public & 4 & 4,5 \\
Regional Development & 10 & 11,2 \\
CG actor & 15 & 16,9 \\
CG dynamics & 21 & 23,6 \\
Ecology/Natural Resources Issue & 16 & 18 \\
Total & 89 & 100 \\
\hline
\end{tabular}

If one were to see the existing classification scheme, it can be understood that the position of research on poverty in the topic of Collaborative Governance is included in the focus of research on the public's social issues. Based on search results, the focus on it has the lowest percentage of only $4.5 \%$.

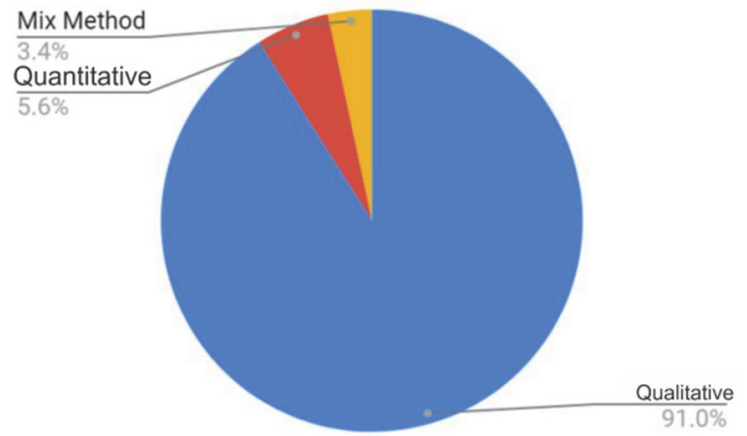

Fig. 6. The Spread of Research Based on Research Method

Source: The Result of Systematic Mapping Study, 2019. 
Based on data from the Systematic Mapping Study, it was revealed that the majority of research on Collaborative Governance was carried out using qualitative methods, shown in Figure 6. The number of studies using qualitative methods reached 81 studies or $91 \%$ of the total research mapped. The other two methods, namely quantitative methods and mixed methods occupy a small portion. A total of 5 researches or $5.6 \%$ were carried out using quantitative methods and a total of 3 studies or $3.4 \%$ were carried out by the mixed method.

Further discussion was carried out by mapping the types of research from mapped researches. There are five types of research from Collaborative Governance research, namely 1) Validation Research; 2) Evaluation Research; 3) Proposal Solution; 4) Philosophical Paper; 5) Experience Paper. Figure 7 below illustrates the distribution of research mapped based on the type of research.

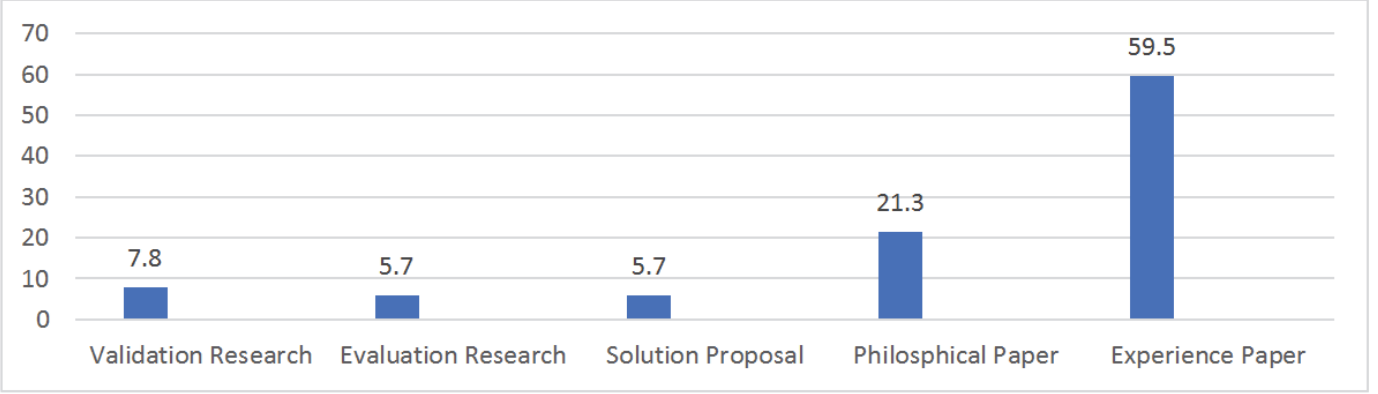

Fig. 7. The Spread of Research Method

Source: The Result of Systematic Mapping Study, 2019.

The research type that is most often done is Experience Paper, which is as much as $59.5 \%$ or 53 studies. The second largest type of research on the research mapped was Philosophical Paper which was $21.3 \%$ of the total research or as many as 19 studies. Three other types of research occupy a small portion of merely $5.7 \%$ or 5 studies for the type of research Evaluation Research and Solution Proposal, while Validation Research only amounted to 7 studies or $7.8 \%$ of the total mapped.

The description of further mapping is done by a combination of research type mapping and research methods. The Systematic Mapping Study revealed that:

1) Collaborative Governance Research that uses qualitative research methods with the type of Experience Paper research is the most widely conducted research (50 research).

2) The second most widely carried out research is research with the Philosophical Paper type of research using Qualitative research methods (18 research).

3) Furthermore, the type of Evaluation Research and Solution Proposal research using qualitative methods each amounted to (5 research).

4) On the other hand, Validation Research that uses quantitative research methods and Validation Research that uses qualitative research methods each amounted to (3 research).

5) Next is research with the type of Experience Paper research that uses mixed methods with a total of (2 research).

6) The amount of research that only amounts to (1 research) is Philosophical paper type research with quantitative methods, Experience Paper with quantitative methods, and Validation Research with mixed methods. 
7) Research that has never been done is Evaluation Research with quantitative method, Solution Proposal with quantitative method, Evaluation Research with mixed method Evaluation Research, Solution Proposal with mixed method, and mixed method Philosophical Paper.

Figure 8 and Table 5 below illustrate the distribution of research maps seen through the type of research and research methods.

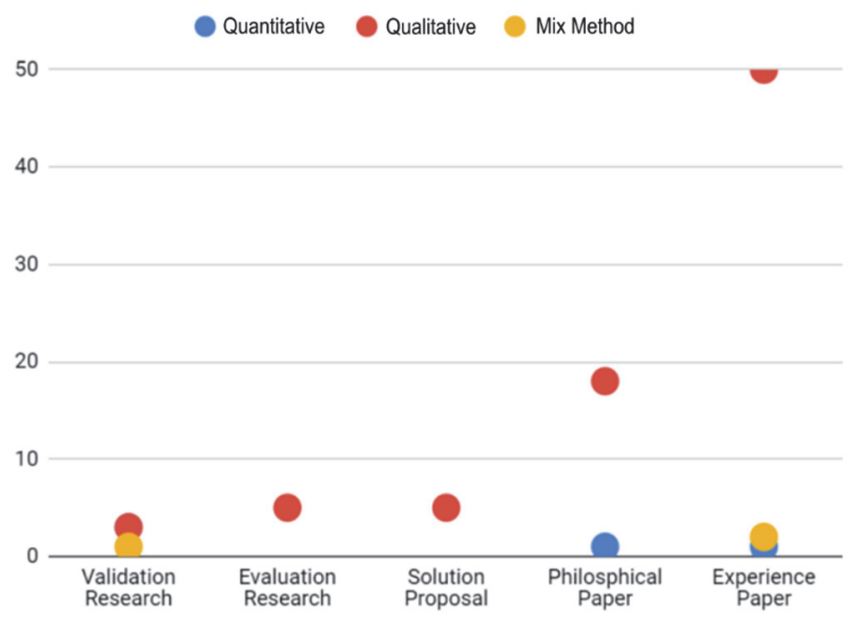

Fig. 8. The Spread of Method Types dan Research Methods

Source: The Result of Systematic Mapping Study, 2019.

Method Spread and Research Type

\begin{tabular}{llll}
\hline Research Type & Quantitative & Qualitative & Mix Method \\
\hline Validation Research & 3 & 3 & 1 \\
Evaluation Research & - & 5 & - \\
Solution Proposal & - & 5 & - \\
Philosophical Paper & 1 & 18 & - \\
Experience Paper & 1 & 50 & 2 \\
\hline
\end{tabular}

Source: The Result of Systematic Mapping Study, 2019.

\section{Publication Trends of Collaborative Governance (2013-2019)}

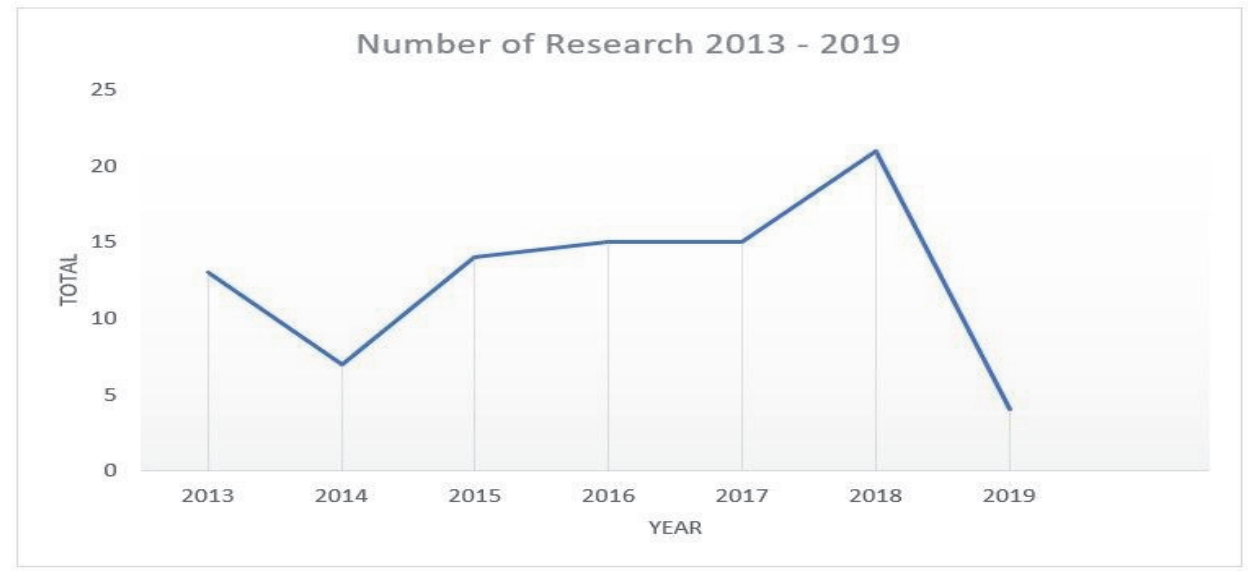

Fig. 9. The Spread of Research Focus

Source: The Result of Systematic Mapping Study, 2019. 
Figure 9 illustrates the research trends published in electronic media: Scopus, Oxford Academic, ProQuest, SAGE Publisher, and Jstor in 2013 to 2019. Based on the search, the publication of Collaborative Governance research decreased from 2013 to 2014 and shows an upward trend from 2014 to 2018. Meanwhile, the publication in 2019 still cannot be concluded since it is still ongoing. Based on these graphs, we can see the highest publication was in 2018, which were 21 publications. Further explanation can be seen in table 6 below.

Table 6

\section{Publication Trend}

\begin{tabular}{ll}
\hline Year & Research Amount \\
\hline 2013 & 13 \\
2014 & 7 \\
2015 & 14 \\
2016 & 15 \\
2017 & 15 \\
2018 & 21 \\
2019 & 4 \\
Total & 89 \\
\hline
\end{tabular}

\section{Conclusion}

Based on the results of the discussion above, here are some points that can be drawn: 1) The most studied 'research focus' is the Collaborative Governance Dynamics (23.6\%) and the least studied 'research focus' is the Social Issues of the Community (4.5\%). The research theme entitled Collaborative Governance for Poverty Alleviation is included in the research focus of Social Issues in the Community. The research focus of Social Issues in the Community in the study has the lowest percentage with $4.5 \%$. 2) The widely used method is the qualitative method with $91 \%$ and the least used method is the mixed method with $3.4 \%$. Whilst the type of research that is widely used is the Experience Paper with 59.5\% and the least is the Evaluation Research and Solution Proposal with 5.7\%; 3) Publication trend shows that the number of publications on Collaborative Governance keep increasing from year to year, with the highest number of researches in 2018.

\section{Future Research}

Collaborative Governance Research with a focus on Social Issues in the Community still shows a research gap. Hence the research on Collaborative Governance for Poverty alleviation has the novelty and deserves to be submitted as a study. Meanwhile, research that has never been conducted is the research with Evaluation Research type with quantitative method, Solution Proposal with quantitative method, and Philosophical Paper with mixed method, thus can be used the method in the future research.

\section{REFERENCES}

[1] Martin K.D., Hill R.P. Life Satisfaction, Self-Determination, and Consumption Adequacy at the Bottom of the Pyramid. Journal of Consumer Research. 2012; 38(6): 1155-68. 
[2] Blocker C.P. Understanding Poverty and Promoting Poverty Alleviation through Transformative Consumer Research. Journal of Business Research. 2013; 66: 1195-1202.

[3] World Development Report 2009: Agriculture for Development. World Bank. Washington: World Bank; 2008.

[4] Larantika A. Collaboration as a Strategy for Poverty Alleviation. International Journal of Social Sciences and Humanities. 2017; 1(3): 40-48.

[5] World Development Report 2005: A Better Investment Climate for Everyone. World Bank. Washington: World Bank; 2005.

[6] Sen A. Development as Freedom. Oxford University Press; 1999.

[7] Florini A., Pauli M. Collaborative Governance for the Sustainable Development Goals. Asia Pac Policy Stud. 2018; 5: 583-598.

[8] World Development Report 2018: Education. World Bank. Washington: World Bank; 2018.

[9] Booher D.E. Collaborative Governance Practices and Democracy. National Civic Review. 2005; 93(4): 32-46

[10] Mattessich P.W., Murray-Close M., Monsey B.R. Collaboration: What Makes It Work. 2nd ed. St. Paul. MN: Amherst H. Wilder Foundation; 2001.

[11] Donahue J. On Collaborative Governance. Corporate Social Responsibility Initiative. Working Paper No. 2. Harvard University; 2004.

[12] Emerson K., Nabatchi T., Balogh S. An Integrative Framework for Collaborative Governance. Journal of Administration Research and Theory. 2012; 1(22): 1-29.

[13] Purdy J.M. A Framework for Assessing Power in Collaborative Governance Processes. Public Administrative Review. 2012; 72(3): 409-417.

[14] McDougall C. Engaging Women and The Poor: Adaptive Collaborative Governance of Community Forests in Nepal. Agriculture and Human Values. 2013; 30: 569-585.

[15] Ansell C., Gash A. Collaborative Governance in Theory and Practice. Journal of Public Administration Research and Theory (JPART). 2007; 18: 543-571.

[16] Gupta S.P. Structural Dimensions of Poverty in India. Delhi: Mittal Publications; 1987.

[17] Suparlan P. Kemiskinan di Perkotaan. Jakarta: Sinar Harapan dan Yayasan Obor Indonesia; 1984 (In Indon.).

[18] Gilarso Pengantar Ilmu Ekonomi Makro. Yogyakarta: Kanisius; 2004 (In Indon.).

[19] Chamsyah B. Teologi Penanggulangan Kemiskinan. Jakarta: PT Gramedia; 2006 (In Indon.).

[20] Marianti R., Wawan M. Moving Out of Poverty: The Case of Desa Branta Pesisir, Kabupaten Pamekasan. Smeru Research Institute; 2006 (In Indon.).

[21] Stamboel K.A. Panggilan Keberpihakan Strategi Mengakhiri Kemiskinan di Indonesia. Jakarta: PT Gramedia; 2012 (In Indon.).

[22] Kessy F.L., Arne T. Out of Poverty: Comparative Poverty Reduction Strategies in Eastern and Southern Africa. Dar es Salaam: Mkuki na Nyota Publishers Ltd; 2008.

[23] Esmara H. Perencanaan dan Pembangunan di Indonesia. Jakarta: Gramedia; 1986 (In Indon.).

[24] Chalid M. Pelaporan Zakat Pengurang Pajak Penghasilan. Jakarta: Raja Grafindo; 2006 (In Indon.).

[25] Sumodiningrat G. Mewujudkan Kesejahteraan Bangsa: Menanggulangi Kemiskinan dengan Prinsip Pemberdayaan Masyarakat. Jakarta: Penerbit Buku Kompas; 2009 (In Indon.).

[26] Kitchenham B., Charters S. Guidelines for Performing Systematic Literature Reviews in Software Engineering. Technical Report EBSE-2007-01. Keele University; 2007.

[27] Petersen K. et al. Systematic Mapping Studies in software engineering. 12th International Conference on Evaluation and Assessment in Software Engineering. 2008; 17: 68-77.

[28] Kitchenham B.A., Dyba T., Jorgensen M. Evidence-based Software Engineering. Software Engineering, 2004. ICSE 2004. Proceedings. 26th International Conference. 2004: 273-281.

[29] Banaeianjahromi N., Kähkönen T., Alanne A., Smolander K. Integration Obstacles during ERP Development. 2016 49th Hawaii International Conference on System Sciences (HICSS). 2016: 4697-4706. 
[30] Musianto L. Perbedaan pendekatan kuantitatif dan pendekatan kualitatif dalam metode penelitian. Jurnal Manajemen \& Kewirausahaan. 2002; 4(2). DOI: https://doi.org/ 10.9744/jmk.4.2.pp.\%20123-136 (In Indon.).

\section{Information about the authors:}

Muh Azis Muslim - M.Sc., Doctoral Student and Lecturer of Faculty of Administrative Science, University of Indonesia (Indonesia) (ORCID ID: 0000-0001-8768-9100) (e-mail: muhazismuslim01@gmail.com).

Eko Prasojo - D.Sc., Professor and Dean of the Faculty of Administrative Science, University of Indonesia (Indonesia) (ORCID ID: 0000-0002-3904-0814) (e-mail: prasojo1@ui.ac.id).

Lina M. Jannah - D.Sc., Head of Academic Quality Assurance and Lecturer of the Faculty of Administrative Science, University of Indonesia (Indonesia) (ORCID ID: 0000-0002-0827-0369) (e-mail: miftahul@ui.ac.id).

\section{Информация об авторах:}

Мух Азис Муслим - магистр, докторант и преподаватель факультета административных наук Индонезийского университета (Индонезия) (ORCID ID: 0000-0001-8768-9100) (e-mail: muhazismuslim01@gmail.com).

Эко Прасойо - доктор наук, профессор и декан факультета административных наук Индонезийского университета (Индонезия) (ORCID ID: 0000-0002-3904-0814) (e-mail: prasojo1@ui.ac.id).

Лина М. Джанна - доктор наук, руководитель отдела обеспечения качества обучения и преподаватель факультета административных наук Индонезийского университета (Индонезия) (ORCID ID: 0000-0002-0827-0369) (e-mail: miftahul@ui.ac.id). 